\title{
A COMPARATIVE STUDY OF MORPHOLOGICAL AND MORPHOMETRIC ANALYSIS OF MENTAL FORAMEN AND ITS CLINICAL IMPORTANCE ON HUMAN DRY MANDIBLES OF SOUTH INDIAN POPULATION
}

\author{
Ravi Varman Chandramohan'1, Shalini Ramanathan², Manoranjitham Rethinasamy33, Veeramuthu Muthulingam ${ }^{4}$ \\ ${ }_{1}^{1}$ Postgraduate, Dept. of Conservative Dentistry and Endodontics, Adhiparasakthi Dental College, Melmaruvathur. \\ ${ }^{2}$ Assistant Professor, Dept. of Anatomy, Dhanalakshmi Srinivasan Medical College and Hospital, Siruvachur, Perambalur, Tamilnadu. \\ 3Professor, Dept. of Anatomy, Dhanalakshmi Srinivasan Medical College and Hospital, Siruvachur, Perambalur, Tamilnadu. \\ ${ }_{4}^{4}$ Tutor, Dept. of Anatomy, Dhanalakshmi Srinivasan Medical College and Hospital, Siruvachur, Perambalur, Tamilnadu.
}

ABSTRACT
BACKGROUND
The mental foramen is an important anatomical and clinical landmark for undertaking a successful mental nerve anaesthetic
block. Mental foramen has many anatomical variations in its size, shape, location and direction of the opening-which are influenced
by gender, age, race, accessing technique used and degree of edentulous alveolar bone atrophy.

\section{AIMS}

The aim of this study is to determine the location, shape, size, direction of the mental foramen and the relation of mental foramen to the surrounding landmarks and also to observe the presence of accessory mental foramen in South Indian adult mandibles.

\section{MATERIALS AND METHODS}

Our study was conducted on 300 adult dry human mandibles. The location, shape and presence of accessory mental foramen was observed macroscopically on both sides of the mandibles. The direction of the mental foramen was assessed with an office pin. The distance of the mental foramen from the processus alveolaris, lower border of the body of the mandible, symphysis menti and posterior border of the ramus of the mandible were measured with digital Vernier callipers. The transverse and vertical diameters of the foramen were measured with digital Vernier callipers. SPSS version 16.0 software was used for the statistical analysis.

\section{RESULTS}

The commonest location of the mental foramen was in line with the $2^{\text {nd }}$ premolar and midway between the processus alveolaris and lower border of body of the mandible on both sides. The commonest shape and direction was oval and posterosuperior direction respectively. The mean vertical diameter and transverse diameter was $2.8 \pm 0.9 \mathrm{~mm}$ and $3.6 \pm 1.2 \mathrm{~mm}$ respectively on the right side and $2.64 \pm 0.9 \mathrm{~mm}$ and $3.3 \pm 1.3 \mathrm{~mm}$ respectively on the left side. Accessory mental foramen was found in $3.33 \%$ of the specimens.

\section{CONCLUSION}

The results of the present study will help the dental surgeons in mental nerve block procedures.

\section{KEYWORDS}

Mandible, Mental foramen, Accessory Mental Foramen, Mental Nerve, Dental Procedures, Premolar, Molar.

HOW TO CITE THIS ARTICLE: Chandramohan RV, Ramanathan S, Rethinasamy M, et al. A comparative study of morphological and morphometric analysis of mental foramen and its clinical importance on human dry mandibles of South Indian population. J. Evolution Med. Dent. Sci. 2016;5(74):5439-5444, DOI: 10.14260/jemds/2016/1232

\section{INTRODUCTION}

One of the most difficult but usual inadvertent complication which can occur during implant placement in anterior mandible is injury to the neurovascular bundle emerging from the mental foramen. This complication can occur if mental foramen and anterior mental loop of mental nerve are not properly identified and protected.[1]

Financial or Other, Competing Interest: None.

Submission 08-08-2016, Peer Review 31-08-2016,

Acceptance 07-09-2016, Published 14-09-2016.

Corresponding Author:

Dr. Shalini Ramanathan,

Assistant Professor,

Department of Anatomy,

Dhanalakshmi Srinivasan

Medical College and Hospital,

Siruvachur, Perambalur, Tamilnadu.

E-mail: liniram80@yahoo.com

DOI: $10.14260 /$ jemds $/ 2016 / 1232$

\section{(c) $(1) \risingdotseq$}

Mental foramen has many anatomical variations in its size, location and direction of the opening, which are influenced by gender, age, race, accessing technique used and degree of edentulous alveolar bone atrophy.[2,3] Consequently, to avoid damage to these vital structures, the exact localisation of the anatomical structures should be identified prior to surgery with thorough knowledge.

The mental foramen, lies on the anterolateral aspect of the body of the mandible, midway between the superior and inferior borders. Near the mental foramen, the inferior alveolar nerve branches into the mental nerve, which leaves the mandible via the mental foramen, and the incisive nerve, which remains within the bone and supplies the anterior teeth. The mental nerve may extend anteriorly for 2-3 $\mathrm{mm}$ within the mandible before curving back to the mental foramen (the 'anterior loop' of mental nerve). The intraosseous anatomy of the mental nerve is of particular importance in dental implant surgery; the nerve may be damaged if the interforaminal area 
of the mandible is invaded during surgery or while harvesting block grafts from the symphyseal region.[4]

Any foramen in addition to the mental foramen in the body of the mandible is known as accessory mental foramen. Accessory mental foramen is due to branching of mental nerve before emerging through mental foramen.[5] The shape, size and verification of existence of accessory mental foramen would prevent accessory mental nerve injury during periapical surgery. In addition to this, if this nerve is not blocked, anaesthesia will be less during mandibular procedures.[6]

The precise knowledge on the variations in the position, shape, and the size of the mental foramen and the presence of the accessory mental foramen would be of much use for dental surgeons while they do surgical procedures on the mandible, such as the curettage of the premolars, filling procedures, dental implants, root canal treatments and orthognathic surgeries.[7] On review of literature, we noted that there were only very few studies on the mental foramen in mandibles of South Indian populations and they have mainly focused on the incidence of accessory mental foramen. ${ }^{[8]}$ In the present study, we have tried to localise the mental foramen in relation to the nearby anatomical landmarks and also analysed the morphological features of the mental foramen in mandibles of South Indian population.

\section{AIMS AND OBJECTIVES}

The aim of this study is to determine the following parameters in dry human mandibles of South Indian population and to compare the results with previous studies on different ethnic groups.

1. Location of mental foramen.

2. Shape, size and direction of mental foramen.

3. Relation of mental foramen with surrounding landmarks.

4. Presence of accessory mental foramen.

\section{MATERIALS AND METHODS}

A total of 300 dry human adult mandibles of unknown sex with teeth intact or with preserved alveolar margins collected from Anatomy and Forensic Medicine Departments and also from the bone collections of medical students of Dhanalakshmi Srinivasan Medical College and Hospital, Perambalur, Tamilnadu, were studied. Damaged and diseased mandibles were excluded from the study.

The location of the mental foramen in relation to mandibular teeth was determined using Tebo and Telford.[9] classification-which is as follows:

1. Mental Foramen between Canine and $1^{\text {st }}$ Premolar.

2. Mental foramen at the level of $1^{\text {st }}$ Premolar.

3. Mental foramen between $1^{\text {st }}$ and $2^{\text {nd }}$ Premolar.

4. Mental foramen at the level of $2^{\text {nd }}$ Premolar.

5. Mental foramen between $2^{\text {nd }}$ Premolar and $1^{\text {st }}$ Molar.

6. Mental foramen at the level of 1 st Molar.

The shape of the mental foramen was observed and determined with the aid of a hand lens. The presence of accessory mental foramen was also observed with a hand lens.

The direction of the mental foramen was measured by inserting an office pin into the foramen from the lateral part of the mandible. The direction to which the office pin pointed was visually inspected.

The results of the different directions or courses of the foramina were then grouped into 4 as follows:

Direction 1: (DI) - Anteriorly.

Direction 2: (D2) - Antero-Superiorly.

Direction 3: (D3) - Postero-Superiorly.

Direction 4: (D4) - Horizontally.

We have localised the position of the mental foramen with respect to the symphysis menti, posterior border of the ramus of the mandible, alveolar margin and base of the mandible according to the study by Voljevica A, et al[10] in Bosnian population. These measurements were measured with a digital Vernier calliper, at a measuring accuracy of $0.01 \mathrm{~mm}$. The transverse and vertical diameters of the mental foramen were also measured with digital Vernier calliper (Figure 1).

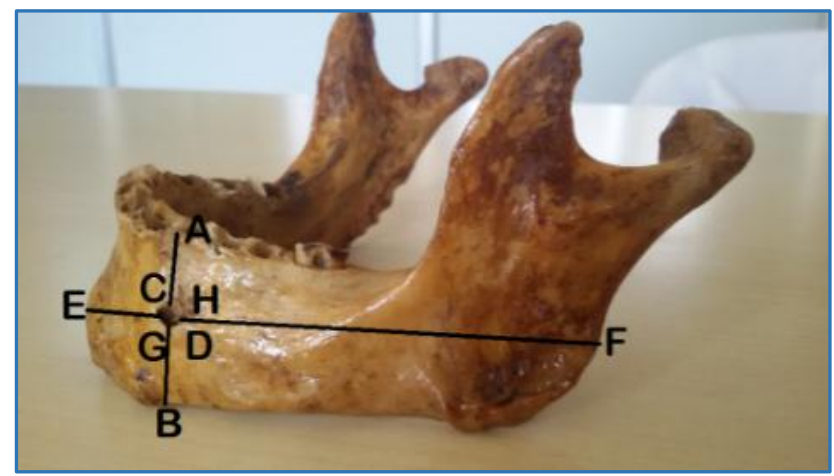

Fig. 1: Position of the Mental Foramen in Relation to the Adjacent Anatomical Landmarks of the Mandible

AC: The distance from the processus alveolaris to the upper edge of Mental foramen. BD: The distance from the lower border of the body of the mandible to the bottom edge of Mental foramen. CD: Vertical diameter of Mental foramen. AB: Height of body of the mandible. EF: The distance from the mental symphysis to the posterior border of the ramus of mandible. FH: The distance from the posterior border of the ramus to posterior edge of the Mental foramen. EG: The distance from the mental symphysis to the anterior edge of Mental foramen. GH: The Horizontal width of the Mental foramen.

All the above measurements and observations were taken on both sides of the mandible. The parameters were carefully tabulated and statistically analysed. SPSS version 16.0 software was used for the statistical analysis of this study. Chisquare was used as a test of significance and 'p' value less than 0.05 was taken to be statistically significant. The results of the present study were compared with the results of previous studies done on various ethnic groups.

\section{RESULTS}

\section{Position of Mental Foramen}

The most prevalent position of the mental foramen in accordance to Tebo and Telford classification [9] was IV in our study. The frequency of position of mental foramen in relation to mandibular teeth is tabulated in Table 1 . The position of the mental foramen was similar on both sides of the body of the mandible in $80 \%$ of the specimens. 
There was no statistically significant difference ( $\mathrm{p}$ value $>$ 0.05 ) in the location of mental foramen on the right and left sides.

\begin{tabular}{|c|c|c|c|c|c|c|c|}
\hline \multirow{2}{*}{ Classification } & Frequency & $\mathbf{\%}$ & $\mathbf{\%}$ & \multirow{2}{*}{ Bilateral } & \multicolumn{2}{|c|}{ Unilateral } \\
\cline { 2 - 7 } & Right & Left & Right & Left & & Right & Left \\
\hline I & Nil & Nil & Nil & Nil & Nil & Nil & Nil \\
\hline II & 12 & 18 & $4 \%$ & $6 \%$ & 12 & Nil & 6 \\
\hline III & 78 & 60 & $26 \%$ & $20 \%$ & 54 & 24 & 6 \\
\hline IV & 156 & 156 & $52 \%$ & $52 \%$ & 138 & 24 & 24 \\
\hline V & 48 & 60 & $16 \%$ & $20 \%$ & 30 & 12 & 24 \\
\hline VI & 6 & 6 & $2 \%$ & $2 \%$ & 6 & Nil & Nil \\
\hline Table 1: Comparison of Frequency of the Position of \\
Mental Foramen in Relation to Mandibular \\
Teeth between Right \& Left Sides \\
\hline
\end{tabular}

\section{Shape of Mental Foramen}

The shape of mental foramen was observed to be either round or oval (Figure $2 \& 3$ ). The frequency of occurrence of the shape of mental foramen is shown in Table 2. There was no statistically significant difference ( $p$ value $>0.05$ ) in the shape of mental foramen on right and left sides.

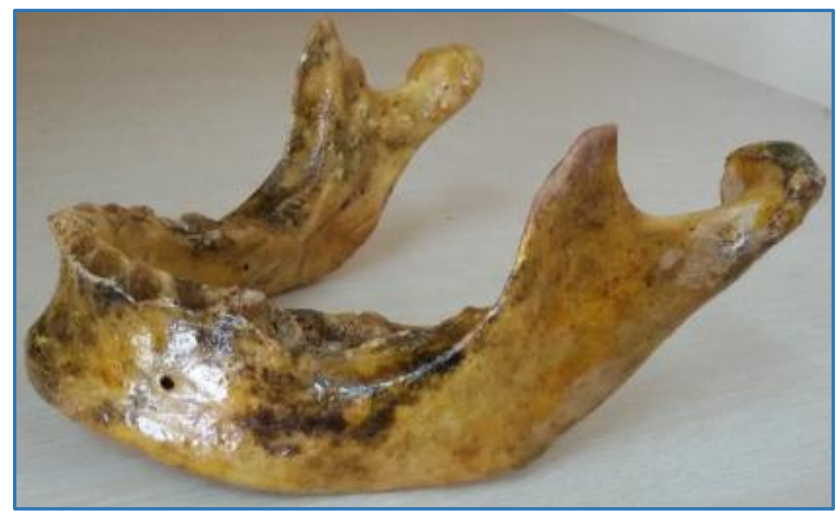

Fig. 2: Left Side of Mandible showing a Round-shaped Mental Foramen

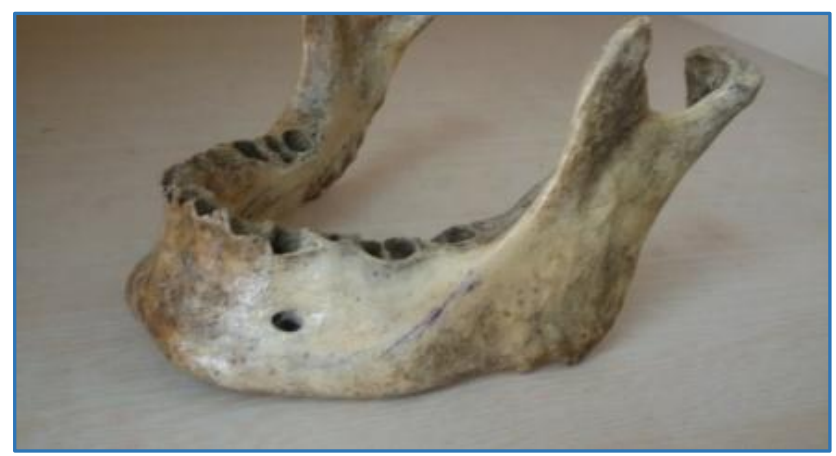

Fig. 3: Left Side of the Mandible showing an Oval-shaped Mental Foramen

\begin{tabular}{|c|c|c|c|c|c|c|c|}
\hline \multirow{2}{*}{ Shape } & Frequency & Percentage & \multirow{2}{*}{ Bilateral } & \multicolumn{2}{|c|}{ Unilateral } \\
\cline { 2 - 7 } & Right & Left & Right & Left & & Right & Left \\
\hline Round & 120 & 132 & $40 \%$ & $44 \%$ & 90 & 30 & 42 \\
\hline Oval & 180 & 168 & $60 \%$ & $56 \%$ & 126 & 54 & 42 \\
\hline Total & $\mathbf{3 0 0}$ & $\mathbf{3 0 0}$ & & & $\mathbf{2 1 6}$ & $\mathbf{8 4}$ & $\mathbf{8 4}$ \\
\hline \multicolumn{8}{|c|}{ Table 2: Shape of Mental Foramen } \\
on Right and Left sides \\
\hline
\end{tabular}

\section{Direction of Mental Foramen}

The frequency of direction of mental foramen is tabulated in Table 3. There was no statistically significant difference ( $p$ value $>0.05$ ) in the direction of mental foramen on the right and left sides.

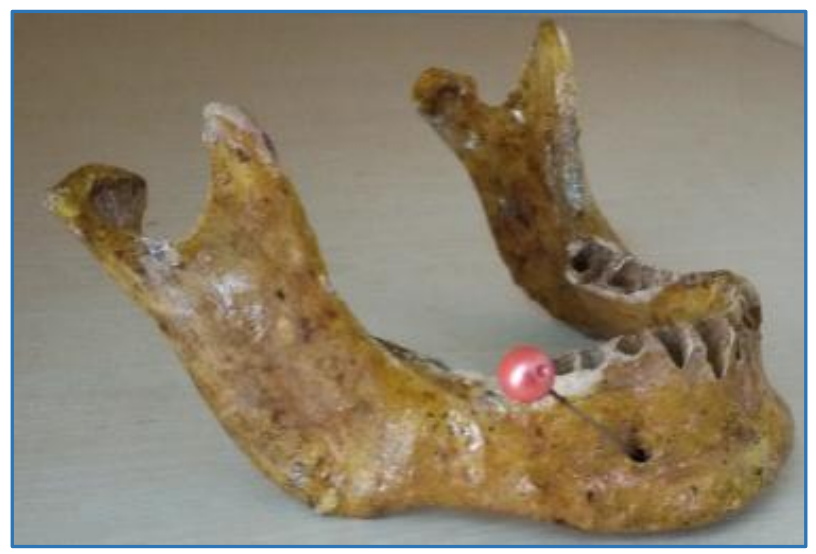

Fig. 4: Right Side of the Mandible with an Office Pin in Mental Foramen indicating the Direction of opening of the Mental Foramen

\begin{tabular}{|c|c|c|c|c|c|}
\hline \multirow{2}{*}{ Direction } & \multirow{2}{*}{ Frequency } & \multirow{2}{*}{$\mathbf{0}$} & \multirow{2}{*}{$\begin{array}{c}\text { Bilateral } \\
\mathbf{6 2 \%}\end{array}$} & & Unilateral 38\% \\
\cline { 5 - 6 } & & & Right & Left \\
\hline D1 & 22 & $3.7 \%$ & 4 & 8 & 6 \\
\hline D2 & 200 & $33.3 \%$ & 51 & 52 & 46 \\
\hline D3 & 284 & $47.3 \%$ & 98 & 37 & 51 \\
\hline D4 & 94 & $15.7 \%$ & 33 & 17 & 11 \\
\hline Total & $\mathbf{6 0 0}$ & $\mathbf{1 0 0 \%}$ & $\mathbf{1 8 6}$ & $\mathbf{1 1 4}$ & $\mathbf{1 1 4}$ \\
\hline \multicolumn{7}{|c|}{ Table 3: Direction of Mental } \\
Foramen on Right and Left Sides \\
\hline
\end{tabular}

Position of Mental foramen and its size calculated by transverse and vertical measurements in relation to borders.

The position of the mental foramen in relation to the processus alveolaris, lower border of the body of the mandible, symphysis menti and posterior border of the ramus of the mandible was determined by taking the measurements shown in Figure 1 on both right and left sides. The results are tabulated in Table 4.

The ratio of distances of mental foramen from symphysis menti (EG) and posterior border of ramus of mandible (FH) is 1: 2.58 on the right side and 1: 2.55 on the left side (Table 4).

There was no statistically significant difference ( $\mathrm{p}$ value $>$ 0.05 ) in the above measurements on right and left sides.

\begin{tabular}{|c|c|c|c|}
\hline \multirow{2}{*}{ Distance } & Side & $\begin{array}{c}\text { Mean } \mathbf{\text { Standard }} \\
\text { deviation in } \mathbf{~ m m}\end{array}$ & Range in $\mathbf{~ m m}$ \\
\hline \multirow{2}{*}{$\mathrm{AC}$} & Right & $12.54 \pm 3.1$ & $5-19$ \\
\cline { 2 - 4 } & Left & $12.1 \pm 2.8$ & $6-18$ \\
\hline \multirow{2}{*}{$\mathrm{BD}$} & Right & $12.9 \pm 2.16$ & $7-19$ \\
\cline { 2 - 4 } & Left & $12.5 \pm 1.9$ & $7-17$ \\
\hline \multirow{2}{*}{$\mathrm{CD}$} & Right & $2.8 \pm 0.9$ & $2-5$ \\
\cline { 2 - 4 } & Left & $2.64 \pm 0.9$ & $1-5$ \\
\hline \multirow{2}{*}{$\mathrm{AB}$} & Right & $26.7 \pm 4.1$ & $16-35$ \\
\cline { 2 - 4 } & Left & $26.5 \pm 4.1$ & $15-35$ \\
\hline \multirow{2}{*}{$\mathrm{EF}$} & Right & $89 \pm 9.1$ & $74-100$ \\
\cline { 2 - 4 } & Left & $88.1 \pm 5.9$ & $73-100$ \\
\hline \multirow{2}{*}{$\mathrm{FH}$} & Right & $64.5 \pm 5.9$ & $48-77$ \\
\cline { 2 - 4 } & Left & $65.6 \pm 5.3$ & $52-71$ \\
\hline \multirow{2}{*}{$\mathrm{EG}$} & Right & $25 \pm 3.1$ & $17-33$ \\
\cline { 2 - 4 } & Left & $25.7 \pm 2.4$ & $20-30$ \\
\hline
\end{tabular}




\begin{tabular}{|c|c|c|c|}
\hline \multirow{2}{*}{ GH } & Right & $3.6 \pm 1.2$ & $1-7$ \\
\cline { 2 - 4 } & Left & $3.36 \pm 1.3$ & $1-6$ \\
\hline \multicolumn{3}{|c|}{ Table 4: Position of Mental Foramen and its size } \\
calculated by Transverse and Vertical measurements \\
in relation to other Parameters between Right \\
and Left Sides
\end{tabular}

\begin{tabular}{|c|c|c|c|c|}
\hline $\begin{array}{l}\text { Position of } \\
\text { Mental } \\
\text { Foramen }\end{array}$ & Right & $\%$ & Left & $\%$ \\
\hline $\begin{array}{c}\text { Near Upper } \\
\text { Border }\end{array}$ & 30 & $10 \%$ & 30 & $10 \%$ \\
\hline At Central & 252 & $84 \%$ & 252 & $84 \%$ \\
\hline $\begin{array}{c}\text { Near Lower } \\
\text { Border }\end{array}$ & 18 & $6 \%$ & 18 & $6 \%$ \\
\hline \multicolumn{5}{|c|}{$\begin{array}{l}\text { Table 5: Position of Mental Foramen on Right and Left } \\
\text { Sides in Relation to Upper and Lower } \\
\text { Borders of Body of Mandible }\end{array}$} \\
\hline
\end{tabular}

\section{Accessory Mental Foramen}

Accessory mental foramen was observed in 10 specimens (3.33\%)-7 on the left side $(2.33 \%)$ and 3 on the right side (1\%). Accessory mental foramen was observed bilaterally in 2 of the specimens. In 4 specimens, the accessory mental foramen was located between the $2^{\text {nd }}$ premolar and $1^{\text {st }}$ molar (Figure 5). In 6 specimens, the accessory mental foramen was found at the level of $1^{\text {st }}$ molar (Figure 6). The average size of the accessory mental foramen was $1 \mathrm{~mm}$.

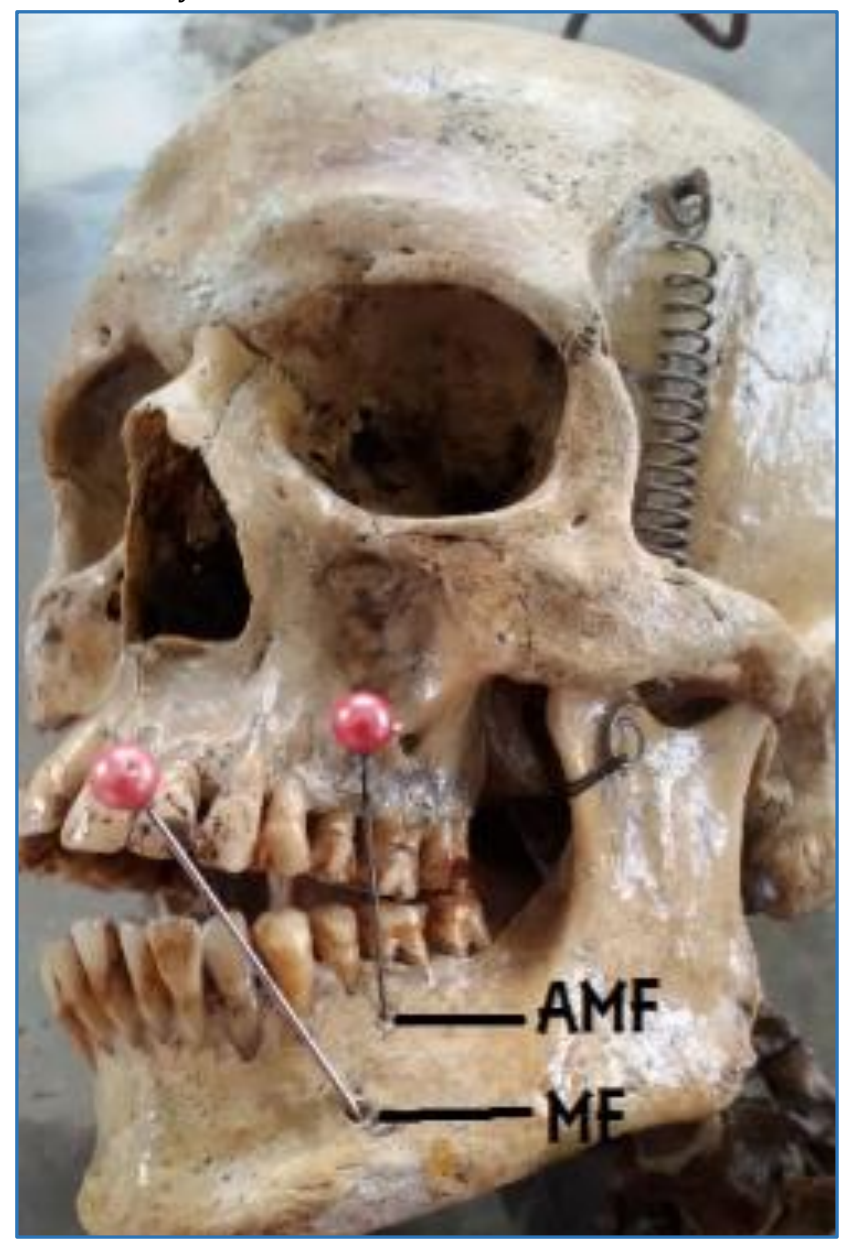

Fig. 5: Left Side of the Mandible showing Accessory Mental Foramen between the $2^{\text {nd }}$ Premolar and the $1^{\text {st }}$ Molar Tooth. MF-Mental Foramen, AMF-Accessory Mental Foramen

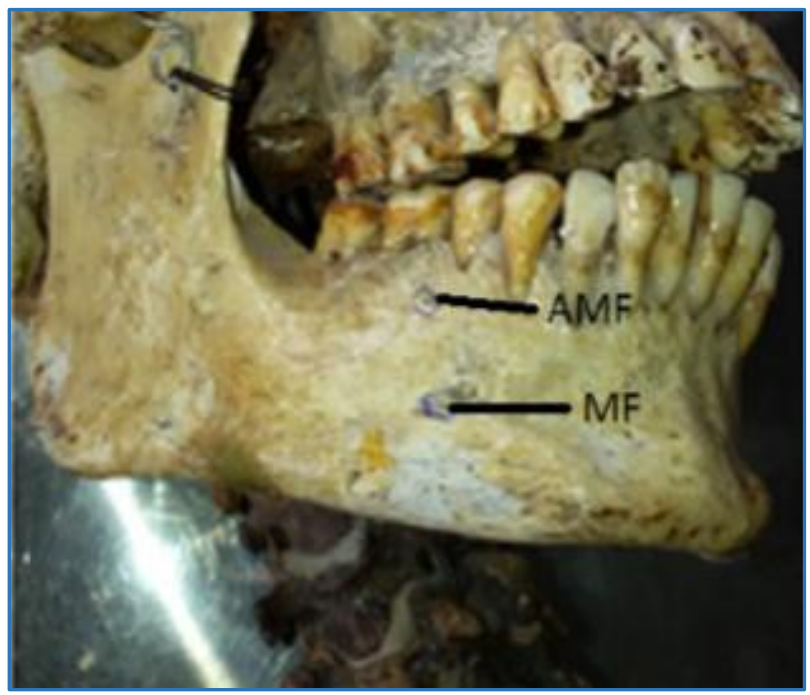

Fig. 6: Right Side of the Mandible showing Accessory Mental Foramen below the $1^{\text {st }}$ Molar Tooth. MF-

Mental Foramen, AMF-Accessory Mental Foramen

\section{DISCUSSION/ Position of Mental Foramen}

The position of mental foramen is important during mental incisive anaesthetic block techniques and surgeries in the outer premolar mandibular region.[11] There are significant differences in the location of the mental foramen among different ethnic groups.[9] Igbigbi and Lebona[12] in Malawian and Mbajiorgu[13] in Zimbabwean mandibles reported position IV as the most common followed by position V. However, Santini and Land[14] in British, and Green[15] in Chinese mandibles observed position III as the most common, followed by position IV. In other studies on Kenyan mandibles, ${ }^{[16]}$ position III was found to be most common, followed by position II, and in the Malay populations[17] the most common position was IV followed by III.

Our results are similar to the studies of Agarwal DR et al[18] on south Gujarat population, Voljevica A, et al[10] on Bosnian population and Budhiraja et al[19] on Indian population-which suggest a common location in the same ethnic group. The location of the mental foramen also depends on the morphology of the root of the mandibular teeth.[4] The location of mental foramen in different population groups is compared in Table 6.

\begin{tabular}{|c|c|c|c|}
\hline Authors & Populations & $\begin{array}{c}\text { Most } \\
\text { Prevalent } \\
\text { Position }\end{array}$ & $\begin{array}{l}\text { 2nd Most }^{\text {nd }} \text { Prevalent } \\
\text { Position }\end{array}$ \\
\hline $\begin{array}{l}\text { Gungor et al } \\
(2006)\end{array}$ & $\begin{array}{l}\text { Turkish } \\
\text { (Europe) }\end{array}$ & III & IV \\
\hline $\begin{array}{l}\text { Moiseiwitsch } \\
\text { (1998) }\end{array}$ & $\begin{array}{c}\text { North } \\
\text { Americans }\end{array}$ & III & IV \\
\hline $\begin{array}{l}\text { Haghanifar \& } \\
\text { Rokouei (2009) }\end{array}$ & $\begin{array}{c}\text { Iranians } \\
\text { (Middle East) }\end{array}$ & III & IV \\
\hline \begin{tabular}{|c|} 
Budhiraja \\
et al (2013) \\
\end{tabular} & Indians (Asia) & IV & III \\
\hline Fabian (2007) & $\begin{array}{l}\text { Tanzanians } \\
\text { (Africa) }\end{array}$ & IV & V \\
\hline $\begin{array}{l}\text { Olsaoji et al } \\
\text { (2004) }\end{array}$ & North Nigerians & III & IV \\
\hline $\begin{array}{c}\text { Ukoha et al } \\
(2013)\end{array}$ & $\begin{array}{l}\text { South Eastern } \\
\text { Nigerians }\end{array}$ & IV & V \\
\hline Present Study & South Indians & IV & III \\
\hline \multicolumn{4}{|c|}{$\begin{array}{c}\text { Table 6: Comparing the Position of the Mental } \\
\text { Foramen in Different Populations [19] }\end{array}$} \\
\hline
\end{tabular}




\section{Shape of Mental Foramen}

Oval-shaped mental foramen was predominantly present in the studies by Mbajiorgu et al[20] Budhiraja et al[19] and Oliveira et al.[21] Round-shaped mental foramen was predominantly observed by Al-Khateeb et al,[22] Singh R and Srivastav AK [6] and Ukoha et al.[20] Comparison of the shapes by previous authors is tabulated in Table 7. The shape of the mental foramen depends upon the direction of emergence of the mental vessels and nerves.[4]

\begin{tabular}{|c|c|c|}
\hline \multirow[t]{2}{*}{ Authors } & \multicolumn{2}{|c|}{ Shapes of Mental Foramen } \\
\hline & Oval & Round \\
\hline Mbajiorgu et al (1998) & $56.3 \%$ & $43.7 \%$ \\
\hline Al-khateeb et al (2007) & Minority & Majority \\
\hline Oliveira, et al (2009) & $72.55 \%$ & $27.45 \%$ \\
\hline $\begin{array}{c}\text { Singh R \& } \\
\text { Srivastav AK (2010) }\end{array}$ & $9.5 \%$ & $90.5 \%$ \\
\hline Budhiraja (2013) & $74.3 \%$ & $25.7 \%$ \\
\hline Ukoha et al (2013) & $24.24 \%$ & $75.76 \%$ \\
\hline Present Study & $58 \%$ & $42 \%$ \\
\hline $\begin{array}{r}\text { Table 7: Com } \\
\text { Shapes of } 1\end{array}$ & $\begin{array}{l}\text { on of } S \\
\text { I Fora }\end{array}$ & \\
\hline
\end{tabular}

\section{Direction of Mental Foramen}

The knowledge of direction of opening of the mental foramen is important to the dental surgeons because it influences the direction in which the needle has to be advanced for a mental nerve block.[21] The posterosuperior direction was also most prevalent in the studies by Agarwal and Gupta in South Gujarat, ${ }^{[18]}$ Mwaniki and Hassanali in Kenyans[16] and Igbigbi and Lebona in Malawians.[12] The mental nerve commonly emerges posterolaterally from the mental foramen, hence posterosuperior direction of opening of mental foramen is commonly noted. $[4]$

Position of Mental foramen and its size calculated by transverse and vertical measurements in relation to the borders of the mandible.

The mental foramen cannot be directly visualised or palpated in clinical situations, hence it is localised in relation to lower jaw teeth.[23] In case of toothless mandibles, the distance of mental foramen from symphysis menti, processus alveolaris, lower border of mandible and posterior border of ramus of mandible are used (Figure 1).

In the study by Mbajiorgu EF et al,[13] the mental foramen was located slightly below the midpoint of the distance between the lower border of the body of mandible and processus alveolaris. Udhaya $\mathrm{K}$ et $\mathrm{al}^{[24]}$ reported that the mental foramen was located in the middle of the vertical plane of the mandible.

The ratio of distances EG and FH was 1:2.6 in Chinese mandibles by Wang TM et al[25] and it was 1:2.7 in British mandibles by Santini and Land.[14] In the present study, the ratio was $1: 2.5$ on both sides (Table 4 ).

Ilayaperuma I et al[26] has reported that the mental foramen was located at a distance of $24.87 \pm 6.07 \mathrm{~mm}$ on the right side and $24.77 \pm 6.07 \mathrm{~mm}$ on the left side lateral to the symphysis menti in Sri Lankan population. Wang TM et al[25] have reported that the distance EG was $28.06 \mathrm{~mm}$ and the distance FH was $74.14 \mathrm{~mm}$.
In the study by Shukla RK et al,[27] the distance EF was $94.33 \pm 5.07 \mathrm{~mm}$ on the left side and $94.22 \pm 4.87 \mathrm{~mm}$ on the right side in North Indian population.

Aphinhasmit et al[2] have reported that the average transverse diameter $(\mathrm{GH})$ of the mental foramen was $2.8 \mathrm{~mm}$. Oguz and Bozkir[28] have reported that the distance GH of the mental foramen was $2.93 \mathrm{~mm}$ on the right side and $3.14 \mathrm{~mm}$ on the left side and vertical diameter (CD) of the mental foramen was $2.38 \mathrm{~mm}$ on the right side and $2.64 \mathrm{~mm}$ on the left side in Turkish mandibles. Voljevica A et al[10] have reported the distance $C D$ of the mental foramen was $1.71+1.02$ $\mathrm{mm}$ on the right side and $1.69 \pm 0.64 \mathrm{~mm}$ on the left side and the distance GH of the mental foramen was $2.56 \pm 1.05 \mathrm{~mm}$ on the right side and $2.41 \pm 0.94 \mathrm{~mm}$ on the left side in Bosnian mandibles.

The position and the dimension of the mental foramen depends on the age changes of the mandible, changing direction of the emergence of mental nerve and also on the morphology of root of mandibular teeth. ${ }^{[4]}$

\section{Accessory Mental Foramen}

Accessory mental foramen is found due to branching of the mental nerve before it emerges out of the mental foramen[5]. Gershenson et al ${ }^{[3]}$ noted accessory mental foramen in $2.8 \%$ of Israeli adult mandibles. In the study by Shukla RK et al,[27] the incidence of accessory mental foramen was $7.2 \%$ in North Indian population. Oliveira JEM et al[21] has reported $5 \%$ incidence of accessory mental foramen. The incidence of accessory mental foramen is $1.8 \%$ for American whites and $12.5 \%$ in Polynesians. [6]

\section{CONCLUSION}

The knowledge of the morphological and morphometric features of the mental foramen and presence of accessory mental foramen is imperative to the dental surgeons in avoiding injury to the mental nerve while performing the periodontal surgery, dental implants, apical curettage of mandibular premolars and endodontic treatments. The results of the present study will be helpful to dental surgeons during mental nerve block procedures in South Indian patients.

\section{REFERENCES}

1. Walton JN. Altered sensation associated with implants in the anterior mandible: a prospective study. J Prosthet Dent 2000;83(4):443-9.

2. Apinhasmit W, Chompoopong S, Methathrathip D, et al. Supraorbital notch/foramen, infraorbital foramen and mental foramen in Thais: anthropometric measurements and surgical relevance. J Med Assoc Thai 2006;89(5):67582.

3. Gershenson A, Nathan H, Luchansky E. Mental foramen and mental nerve: changes with age. Acta Anat (Basel) 1986;126(1):21-8

4. Standring S. Gray's anatomy. The anatomical basis of clinical practice. $40^{\text {th }}$ edn. Edinburg: Churchill and Livingstone 2008:530-2.

5. Sawyer DR, Kiely ML, Pyle MA. The frequency of accessory mental foramina in four ethnic groups. Arch Oral Biol 1998;43(5):417-20.

6. Singh R, Srivastav AK. Study of position, shape, size and incidence of mental foramen and accessory mental 
foramen in Indian adult human skull. Int J Morphol 2010;28(4):1141-6.

7. Vimala V, Rohinidevi M, Mekala D. Study of anatomical variations of mental foramen in dry adult human mandibles and its clinical importance. IOSR-JDMS 2015;14(9):40-44.

8. Nandakumar, Thenmozhi. A study of incidence of accessory mental foramen in south Indian mandibles. J Pharm Sci \& Res 2015;7(7):445-7.

9. Tebo HG, Telford IR. An analysis of the variations in position of the mental foramen. Anat Rec 1950;107(1):61-6.

10. Voljevica A, Talovic E, Hasanovic A. Morphological and morphometric analysis of the shape, position, number and size of mental foramen on human mandibles. Acta Medica Academica 2015;44(1):31-8.

11. Greenstein G, Tarnow D. The mental foramen and nerve: clinical and anatomical factors related to dental implant placement-a literature review. J Periodontol 2006;77(12):1933-43.

12. Igbigbi PS, Lebona $S$. The position and dimensions of the mental foramen in adult Malawian mandibles. West Afr J Med 2005;24(3):184-9.

13. Mbajiorgu EF, Mawera G, Asala SA, et al. Position of the mental foramen in adult black Zimbabwean mandibles: a clinical anatomical study. Cent Afr J Med 1998;44(2):2430.

14. Santini A, Land M. A comparison of the position of the mental foramen in Chinese and British mandibles. Acta Anat (Basel) 1990;137(3):208-12.

15. Green RM. The position of the mental foramen: a comparison between the southern (Hong Kong) Chinese and other ethnic and racial groups. Oral Surg Oral Med Oral Pathol 1987;63(3):287-90.

16. Mwaniki DL, Hassanali J. The position of mandibular and mental foramen in Kenyan African mandibles. East Afr Med J 1992;69(4):210-3.

17. Ngeow WC, Yuzawati Y. The location of the mental foramen in a selected Malay population. J Oral Sci 2003;45(3):171-5.
18. Agarwal DR, Gupta SB. Morphometric analysis of mental foramen in human mandibles of south Gujarat. People's Journal of Scientific Research 2011;4(1):15-8.

19. Budhiraja V, Rastogi R, Lalwani R, et al. Study of position, shape and size of mental foramen utilizing various parameters in dry adult human mandibles from north India. ISRN Anatomy Article ID 961429, 2013;2013:5 pages.

20. Ukoha UU, Umeasalugo KE, Ofoego UC, et al. Position, shape and direction of the mental foramen in mandibles in south-eastern Nigeria. IJBR 2013;4(9):499-503.

21. Oliveira EM, Araujo ALD, Da Silva CMF, et al. Morphological and morphometric study of the mental foramen on the M-CP-18 Jiachenjiang point. International Journal of Morphology 2009;27(1):231-8.

22. Al-Khateeb T, Al-Hadi HA, Ababneh KT. Position of the mental foramen in a northern regional Jordanian population. Surgical and Radiologic Anatomy 2007;29(3):231-7.

23. Phillips JL, Weller RN, Kulild JC. The mental foramen: size, orientation and positional relationship to the mandibular second premolar. J Endod 1990;16(5):221-3.

24. Udhaya K, Saraladevi KV, Sridhar J. The morphometric analysis of mental foramen in dry human mandible: a case report. Journal of Clinical and Diagnostic Research 2013;7(8):1547-51.

25. Wang TM, Shih C, Liu JC, et al. A clinical and anatomical study of the location of the mental foramen in adult Chinese mandibles. Acta Anat (Basel) 1986;126(1):29-33.

26. Ilayaperuma I, Nanayakkara G, Palahepitiya N. Morphometric analysis of the mental foramen in adult Sri Lankan mandibles. Int J Morphol 2009;27(4):1019-24.

27. Shukla RK, Gupta P, Hussein M, et al. Morphometric measurement of mental foramen in dry human mandible in north Indian population. Int J Anat Res 2015;3(1):899905.

28. Oguz 0, Bozkir MG. Evaluation of location of mandibular and mental foramina in dry, young, adult male, dentulous mandibles. West Indian Med J 2002;51(1):14-16. 